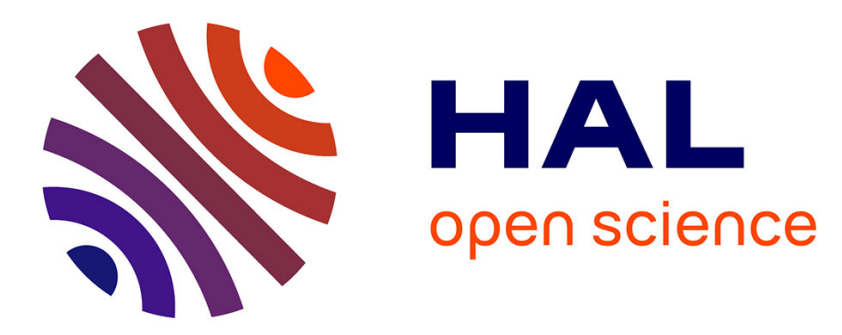

\title{
Comments on the paper 'Flow regime and liquid-solid mass transfer investigation in a designed porous structure using electrochemical micro-probes' by Altheimer et al. (2016) \\ Florian Huchet
}

\section{To cite this version:}

Florian Huchet. Comments on the paper 'Flow regime and liquid-solid mass transfer investigation in a designed porous structure using electrochemical micro-probes' by Altheimer et al. (2016). Chemical Engineering Science, 2017, 163, pp.255-256. 10.1016/j.ces.2017.01.038 . hal-01586018v2

\section{HAL Id: hal-01586018 \\ https://hal.science/hal-01586018v2}

Submitted on 18 Oct 2017

HAL is a multi-disciplinary open access archive for the deposit and dissemination of scientific research documents, whether they are published or not. The documents may come from teaching and research institutions in France or abroad, or from public or private research centers.
L'archive ouverte pluridisciplinaire HAL, est destinée au dépôt et à la diffusion de documents scientifiques de niveau recherche, publiés ou non, émanant des établissements d'enseignement et de recherche français ou étrangers, des laboratoires publics ou privés. 


\title{
Comments on the paper "Flow regime and liquid-solid mass transfer investigation in a designed porous structure using electrochemical micro-probes" by Altheimer et al.
}

(2016)

\author{
Florian Huchet \\ LUNAM, University of Nantes, IFSTTAR, MAST Dept., GPEM Lab \\ Route de Bouaye - CS 4, 44344 Bouguenais cedex
}

The paper entitled "Flow regime and liquid-solid mass transfer investigation in a designed porous structure using electrochemical micro-probes" is devoted to application of an ElectroDiffusion (ED) method to study the identification of flow regimes and the wall mass transfer into a porous structure. A three-dimensional geometry, with a mean porosity equal to 0.7, was generated from a stereolithographic process using a liquid polymer resistant to the electrolytic solution. The micro-probes working as a cathode were connected from pins, which themselves were connected within the porous structure. Despite the appropriate use of this ED technique to identify the onset of wall shear rate fluctuations, the reliance on identical microelectrodes for measuring the average liquid/solid mass transfer remains a matter of discussion. It is highly likely that the level of performance reported, regarding the wall mass transfer found at the macro-scale of the studied system, has been overestimated. In the limiting diffusional regime at the cathode surface, the use of microelectrodes is widely known to capture the wall shear rate, based on a linear theory established in the thicknesses of the diffusion and hydrodynamic boundary layers. The diffusion-convection equation is solved in the vicinity of the microelectrode, thus leading to an analytical relationship between the local wall mass transfer $\left(\bar{k}_{x}\right)$, which itself is correlated with the measured limiting diffusion current (Eq. 5 in the paper by Altheimer et al. (2016)), and the wall shear rate (Eq. 6). These relationships were analytically demonstrated by Reiss and Hanratty (1963); the physical principle being based on the developing of the concentration boundary layer above an electrochemical micro-probe. None of the underlying assumptions have been mentioned in the reviewed paper, even though one of them is crucial, namely: the size of the microelectrode must be of the same order of magnitude as the turbulent eddies. In Altheimer et al. (2016), the size of the microelectrode has been set equal to $0.4 \mathrm{~mm}$. Flow uniformity above the electrochemical sensor is another important issue; the circular probe flush-mounted to the wall is capable of producing diffusional edge effects. Moreover, many authors have demonstrated the relevance of this method to capture the turbulent eddies in the near-wall region of numerous complex flows (Deslouis et al., 1991; Legrand et al., 1998; Seguin et al., 1998b). The instantaneous limiting diffusion current (or concentration) may be related to the instantaneous wall shear rate in order to capture the onset of wall flow fluctuations. The authors have achieved a signal analysis procedure to convert the current fluctuations, recorded at a high sampling frequency, into the power density spectrum of shear rate fluctuations. The onset of fluctuations at a Reynolds number equal to 162 is found to be in agreement with the flow measurements performed through packed beds (Seguin et al. 1998a). Nevertheless, the results contained in the last part of the paper (Section 5.4) raise considerable doubts since the authors also favor employing such micro-probes to characterize average wall mass transfer at the scale of a four-unit cells representative of the porous structure. The results of the average wall mass transfer are therefore questionable and likely to be overestimated. The authors have measured the local mass transfer $\bar{k}_{x}$, spatially averaged at the micro-probe surface, as characterized by a thin concentration boundary layer. The size of the electrode governs the length of development of the concentration boundary layer. Due to a higher local concentration gradient occurring in the vicinity of the microelectrode, the local mass transfer 
thus increases as the electrode becomes smaller. This dependence of the size of the microelectrode on the local mass transfer magnitude was noted in the article by Reiss and Hanratty (1963) (see Figure 2 in the MS) as follows: "The average mass transfer coefficient increases with decreasing electrode size". Consequently, the local mass transfer $\bar{k}_{x}$ is slightly non-representative of the overall liquid-solid mass transfer, $K$, yet in the results presented, only the fluctuation rates of the current are deemed relevant. Generally speaking, the authors implement a working electrode with a large active surface area in order to measure the liquid/solid mass transfer (see, for example, Montillet et al. (1994) or Huchet et al. (2007)). Altheimer et al. (2016) have thus compared their local mass transfer results with the average liquid-solid mass transfer measured from three macro-electrodes mounted in a well-designed geometry (Huchet et al. (2007)), composed of a network of crossing minichannels. This millifluidic device was designed to mimic porous media and the results (Huchet et al. (2007)) have shown that the liquid-solid mass transfer is similar to the values established in the packed beds of spheres (Wakao and Funazkri, 1978), whereby:

$$
\begin{gathered}
S h S c^{-1 / 3}=0.94 R e^{0.41} \text { for } R e<100(1) \\
S h S c^{-1 / 3}=\frac{1}{3} R e^{0.6} \text { for } R e>200(2)
\end{gathered}
$$

A comparison of the porous structure studied in Altheimer et al. (2016) with the geometry studied in Huchet et al. (2007) appears to be unsuitable due to the aforementioned comments, while the rise in the liquid-solid mass transfer underscored in their conclusion is likely to have been overestimated.

\section{$\underline{\text { Nomenclature }}$}

$\begin{array}{clc}d & \text { Hydraulic or pore diameter } & {[\mathrm{m}]} \\ \mathrm{D} & \text { Diffusion coefficient } & {\left[\mathrm{m}^{2} \cdot \mathrm{s}^{-1}\right]} \\ \bar{k}_{x} & \text { Local mass transfer coefficient } & {\left[\mathrm{m}_{\mathrm{s}} \mathrm{s}^{-1}\right]} \\ \mathrm{K} & \text { Overall mass transfer coefficient } & {\left[\mathrm{m} . \mathrm{s}^{-1}\right]} \\ v & \text { Kinematic viscosity } & {\left[\mathrm{m}^{2} \mathrm{~s}^{-1}\right]} \\ \mathrm{u} & \text { Velocity } & {\left[\mathrm{m} . \mathrm{s}^{-1}\right]} \\ S h=K d / D & \text { Sherwood number } & {[-]} \\ S c=v / D & \text { Schmidt number } & {[-]} \\ \operatorname{Re}=u d / v & \text { Reynolds number } & {[-]}\end{array}$

\section{$\underline{\text { References }}$}

Altheimer M., Becker D., D’Aleo P., Von Rohr P.R., (2016) Flow regime and liquid-solid mass transfer investigation in a designed porous structure using electrochemical micro-probes, Chem. Eng. Sci., 152 699-708.

Reiss L.P., Hanratty T.J. (1963) An experimental study of the unsteady nature of the viscous sublayer, AIChE J. 8, 154-160.

Deslouis C., Huet F., Robin S., Tribollet B., 1991, Spectral analysis of wall turbulence with photolithography devised electrochemical probes, Int. J. Heat Mass Transfer, 36 3, 823-829. 
Montillet A., Comiti J., Legrand J., 1994, Application of metallic foam in electrochemical reactors of the filter-press type: Part 2 Mass transfer Performance, J. Appl. Electrochem. 24 384-389.

Seguin D., Montillet A., Comiti J., 1998 a., Experimental characterization of flow regimes in various porous media-I: Limit of laminar flow regime, Chem. Eng. Sci. 53, 3751-3761.

Seguin D., Montillet A., Comiti J., Huet F., 1998 b., Experimental characterization of flow regimes in various porous media II: Transition to turbulent regime, Chem. Eng. Sci. 53, 38973909.

Legrand J., Aouabed H., Legentilhomme P., Lefèvre G., Huet F., 1997, Use of electrochemical sensors for the determination of wall turbulence characteristics in annular swirling decaying flows, Exp. Therm. Fluid Sci., 15, 125-136.

Huchet F., Comiti J., Tihon J., Montillet A., et Legentilhomme P., Electrodiffusion diagnostics of the flow and mass transfer inside a network of crossing minichannels. J. Appl. Electrochem., 37 1 49-55 (2007).

Wakao N., Funazkri T., 1978, Effect of fluid dispersion coefficients on particle-to-fluid mass transfer coefficients in packed beds. Correlation of Sherwood numbers, Chem. Eng. Sci., 33, $1375-1384$. 